GRASAS Y ACEITES 68 (3)

July-September 2017, e211

ISSN-L: 0017-3495

doi: http://dx.doi.org/10.3989/gya.0111171

\title{
Chemical characterization and thermal properties of kernel oils from Tunisian peach and nectarine varieties of Prunus persica
}

\author{
D. Chamli ${ }^{\mathrm{a}, \mathrm{b}}$, M.A. Bootello ${ }^{\mathrm{a}}$, I. Bouali ${ }^{\mathrm{b}}$, S. Jouhri ${ }^{\mathrm{b}}$, S. Boukhchina ${ }^{\mathrm{b}}$ and E. Martínez-Force ${ }^{\mathrm{a}, \bigotimes}$ \\ ${ }^{a}$ Instituto de la Grasa, CSIC, Edificio 46, Campus Universidad Pablo de Olavide, \\ Ctra. de Utrera Km 1, 41013-Sevilla, Spain. \\ ${ }^{\mathrm{b}}$ Laboratoire de biochimie des lipides, Département de Biologie, Faculte des sciences de Tunis, \\ 2092 El Manar-Tunisie. \\ ${ }^{\square}$ Corresponding author: emforce@ig.csic.es
}

Submitted: 26 January 2017; Accepted: 07 June 2017

SUMMARY: A comparative study was conducted to determine the fatty acids, triacylglycerol compositions and thermal properties of Tunisian kernel oils from the Prunus persica varieties, peach and nectarine, grown in two areas of Tunisia, Gabes and Morneg. Qualitatively, the fatty acids composition and triacylglycerol species were identical for all samples. Oleic acid $(67.7-75.0 \%)$ was the main fatty acid, followed by linoleic (15.7-22.1\%) and palmitic (5.6-6.3\%) acids. The major triacylglycerol species were triolein, OOO (38.4-50.5\%), followed by OOL $(18.2-23.2 \%)$, POO $(8.3-9.7 \%)$ and OLL $(6.3-10.1 \%)$. The thermal profiles were highly influenced by the high content of triolein due to the importance of oleic acid in these oils. Moreover, the fatty acids distribution in TAG external positions was determined as corresponding to an $\alpha$ asymmetry coefficient that was between 0.10 and 0.12 , indicating a high asymmetry in the distribution of saturated fatty acids in the position $s n-1$ and $s n-3$ in the TAG species of all samples.

KEYWORDS: DSC; Fatty acids; Kernel oils; Nectarine; Peach; Prunus persica; Triacylglycerols

RESUMEN: Caracterización química y propiedades térmicas de los aceites de semillas de variedades tunecinas de melocotón y nectarina de Prunus pérsica. Se ha realizado un estudio comparativo de aceites tunecinos obtenidos a partir de las semillas de variedades de Prunus persica, melocotón y nectarina, cultivadas en dos zonas de Túnez, Gabes y Morneg. Cualitativamente, la composición de ácidos grasos y de especies de triglicéridos fueron idénticas para todas las muestras. El ácido oleico $(67,7-75,0 \%)$ fue el ácido graso principal, seguido del linoleico $(15,7-22,1 \%)$ y el palmítico $(5,6-6,3 \%)$. Las especies principales de triacilglicéridos fueron la trioleina, OOO $(38,4-50,5 \%)$, seguida de OOL (18,2-23,2\%), POO (8,3-9,7\%) y OLL (6,3-10,1\%). Los perfiles térmicos fueron muy influidos por el alto contenido de trioleina debido a la importancia del ácido oleico en estos aceites. Por otra parte, se determinó la distribución de ácidos grasos en las posiciones externas de los TAG correspondiendo a un coeficiente de asimetría $\alpha$ entre 0,10 y 0,12 , lo que indica una alta asimetría en la distribución de los ácidos grasos saturados en la posición $s n-1$ y $s n-3$ en las especies de los TAG de todas las muestras.

PALABRAS CLAVE: Aceites de semilla; Ácidos grasos; DSC; Melocotón; Nectarina; Prunus persica; Triacilglicéridos

ORCID ID: Chamli D http://orcid.org/0000-0002-9921-7546, Bootello MA http://orcid.org/0000-0003-4962-2751, Bouali I http://orcid.org/0000-0001-6955-8027, Jouhri S http://orcid.org/0000-0001-6620-4792, Boukhchina S http:// orcid.org/0000-0003-1215-2813, Martínez-Force E http://orcid.org/0000-0001-5324-9537

Citation/Cómo citar este artículo: Chamli D, Bootello MA, Bouali I, Jouhri S, Boukhchina S, Martínez-Force E. 2017. Chemical characterization and thermal properties of kernel oils from Tunisian peach and nectarine varieties of Prunus persica. Grasas Aceites 68 (3), e211. http://dx.doi.org/10.3989/gya.0111171

Copyright: (C2017 CSIC. This is an open-access article distributed under the terms of the Creative Commons Attribution (CC-by) Spain 3.0 License. 


\section{INTRODUCTION}

In the last decades, developed countries have been trying to reduce their energetic dependence from fossil fuels and their derivatives. Vegetable oils, due to their chemical nature, have been the focus of a great part of the efforts directed to this purpose. Nevertheless, the main uses of the oleaginous crops produced worldwide (palm, soybean, canola, sunflower, olive, etc...) are limited to edible applications within the food processing industry. Since non-edible uses of these oils (fuel, lubricants or oleo-chemicals) would be problematic and unsustainable, research has been directed toward the use of oils from non-extensively cultivated species or the utilization of unusual sources, such as waste oils or by-products of the food processing industry.

Fruits from genus Prunus are qualified as drupes, membranous exocarp with an outer fleshy mesocarp. They are categorized as stone fruits because their seeds are inside a hard stone (Ram and Bhardwaj, 2004). Prunus persica is one of the species of the Rosaceae family that is widely distributed in most countries around the world. Peach and nectarine, a peach variety bearing fruits with smooth skin, are the second most important fruit crop in the European Union (EU) (approx. 3.8 million tons) after the apple (FAOSTAT, 2013), and the most important within the genus Prunus (Di vaio et al.,2008). The pulp from peaches and nectarines is used directly for jams and canned food or diluted to prepare commercial or domestic juices (Bates et al., 2001). In addition, the leaves of the peach tree are used for the treatment of irritated digestive tract and constipation (Gilani et al., 2000).

The kernel is considered an important food source with a high nutritional value, mostly due to its oil and protein contents (Sabate and Hook, 1996; Socias i Company et al., 2010), but they are usually destined to animal feed or used as fuel (Mezzomo et al., 2009). The kernel has a slightly toxic effect due to its content in hydrogen cyanide, so any excessive human use can cause headache, blurred vision, palpitations, or even death from respiratory failure (Wu et al., 2011). Its nutritional value is due to the high value of unsaturated fatty acids, mostly the monounsaturated fatty acids (MUFA). Several Clinical studies reported that an important consumption of monounsaturated fats in the diet reduce the prospect of cardiovascular diseases (Visioli et al., 2002) by reducing the low density lipoprotein cholesterol levels in the blood (Sorci-Thomas et al., 1989). However, each year, thousands of tons of stones (pericarp plus kernel) from peaches and nectarines are wasted as a by-product of the production of juices and jams.

Most oils and fats are mainly composed of a great variety of triacylglycerol (TAG) species, comprising of 96 to $99 \%$ of total lipids. In chemical terms, TAGs consist of a glycerol molecule esterified to three fatty acids. Therefore, vegetable oils and fats can be further classified according to their fatty acids and TAG species compositions. The analysis of TAG composition is used as reference to characterize oils or fats because they contain structural information, such as the position of the fatty acid (FA) residues on the glycerol backbone. This information is lost in the transesterification reaction which is necessary for FA analysis by GLC (Tan and Che, 2000). Furthermore, oil industrial uses are influenced by the amount of tri-, di- and mono-saturated TAG species (Martinez-Force et al., 2004). For this reason, an asymmetric $\alpha$ coefficient was developed to explain the stereochemical distribution of fatty acids in the TAG molecule. This method is based on the data obtained from the fatty acid composition of TAG, the profile of TAG species, and the fatty acid content of the $s n-2$ position of TAG (Ruiz-Lopez et al., 2003).

The phytochemical contents of fruits are influenced by numerous factors such as genotype, storage and climatic conditions, agronomic practices, harvesting time and post-harvest conditions (Cantin et al., 2009). In addition, the physical, and nutritional properties of oils are affected by TAG species composition and their stereo-specificity (Ruiz-Lopez et al., 2003). Until now, no one has characterized the oil quality from nectarine fruits, assuming that it is similar to peach in fatty acids and minor components. Due to their fatty acids compositions, peach and nectarine oils can be considered as valuable oils for industrial uses when compared with sunflower and rapeseed oils.

The aim of this work was to establish a comparative study between Tunisian peach and nectarine varieties of Prunus persica. A characterization of the physicochemical properties of the kernel oils was made to evaluate their nutritive value and to determine the environmental effect of two different production regions on kernel oil content and composition.

\section{MATERIALS AND METHODS}

\subsection{Plant material}

Peach (P) and nectarine (N) fruits were collected from trees growing wild in two Tunisian regions, Morneg $(\mathrm{Mg})$ and Gabes $(\mathrm{Gb})$, in July 2014. Morneg is located in the area of Ben Arous in the northeast of Tunisia, at $36^{\circ} 44^{\prime} \mathrm{N}$ latitude and $10^{\circ} 13^{\prime} \mathrm{E}$ longitude. The altitude above sea level is 12 meters. The station of Gabes is located in the southeast of Tunisia, at $33^{\circ} 52^{\prime} \mathrm{N}$ latitude and $10^{\circ} 05^{\prime} \mathrm{E}$ longitude. The altitude sea level is nine meters. From each station, fruits from each variety were collected, the mesocarp and stony endocarp were separated, and the kernels from the endocarps were mixed and 
placed in an oven at $60^{\circ} \mathrm{C}$ until dried and kept at a constant weight.

The dried samples were reduced in powder using a manual mortar. The oils were extracted by a Soxhlet apparatus for four hours using petroleum ether as solvent. This was evaporated under reduced pressure, using a rotary evaporator at $50^{\circ} \mathrm{C}$. The obtained oil was dried with a stream of nitrogen, weighed and stored in dark glass bottles at $4{ }^{\circ} \mathrm{C}$ until analysis. Samples from each crop were taken in triplicate.

\subsection{Lipids analysis}

The lipid fractions were determined by dissolving $6 \mathrm{mg}$ of oil in $500 \mu \mathrm{L}$ of chloroform. The resulting solution was fractionated in a Lichrolut $0.5 \mathrm{~g}$ silica gel cartridge (Merck) using a vacuum manifold and then equilibrated with $2 \mathrm{~mL}$ of chloroform (Nash and Frankel, 1986). The solution of total lipids was loaded onto the column which was then washed with another $15 \mathrm{~mL}$ of chloroform to elute neutral lipids from the column. Subsequently, the column was washed with $10 \mathrm{~mL}$ of methanol to recover the polar lipids quantitatively.

The fatty acids composition was determined by derivatizing $6 \mathrm{mg}$ of the oil fractions to their corresponding fatty acid methyl esters for $1 \mathrm{~h}$ at $80{ }^{\circ} \mathrm{C}$ with $2 \mathrm{~mL}$ methanol/toluene/sulphuric acid (85/15/2.5, v/v/v) (Garcés and Mancha, 1993). Fatty acid methyl esters were extracted with $2 \mathrm{~mL}$ heptane and analyzed by gas chromatography (GC) on an Agilent 6890 gas chromatography system (Palo Alto, CA) according to the method used by Bootello et al. (2016).

The analysis of TAGs of the different oil fractions was carried out by injecting $1 \mu \mathrm{L}$ aliquots of $5 \mathrm{mg}$ of oil dissolved in $1.8 \mathrm{~mL}$ of heptane into an Agilent 7890 gas chromatograph (Palo Alto, CA) using the same chromatographic conditions as reported by Bootello et al. (2016).

For the positional analysis of TAG $s n-2$ fatty acids, $10 \mathrm{mg}$ of purified TAGs were hydrolyzed with $2 \mathrm{mg}$ of pancreatic lipase in $1 \mathrm{~mL}$ of a $1 \mathrm{M}$ Tris$\mathrm{HCl}$ buffer (pH8), $0.1 \mathrm{~mL} \mathrm{CaCl}_{2}(22 \%)$, and $0.25 \mathrm{~mL}$ deoxycholate $(0.1 \%)$. The reaction was stopped when approximately $60 \%$ of the TAGs were hydrolyzed (1-2 min) by adding $0.5 \mathrm{~mL}$ of $6 \mathrm{~N} \mathrm{HCl}$. The lipids were extracted three times with $1.5-\mathrm{mL}$ aliquots of ethyl ether, and the reaction products were separated by TLC. Free fatty acids and $s n-2$-monoacylglycerol bands representing the positions $s n-1,3$ and $s n-2$ of TAGs were scraped off the plate, trans-methylated and analyzed by GC. The validity of the procedure was confirmed by comparing the fatty acids composition of the original TAGs and those remaining after the partial hydrolysis. The distribution of saturated fatty acids between the $s n-1$ and $s n-3$ external positions of TAGs was calculated using the coefficient of asymmetry $\alpha$ as the quotient between subclasses Saturated-Unsaturated-Saturated and Saturated-Unsaturated-Unsaturated ( $\alpha$ SUS/SUU) (Martínez-Force et al., 2009). Thus, $\alpha$ can range between 0 and $0.5 ; \alpha=0.5$ indicates a symmetrical distribution of saturated fatty acids in accordance with the Vander Wal theory (Vander Wal, 1960).

\subsection{Calorimetric analysis by DSC}

The melting and crystallization profiles of the different oils were determined by differential scanning calorimetry (DSC) using a Q2000 V23.5 scanner (TA instruments, New Castle, DE, USA). The results were processed using the TA analysis software provided by the manufacturer. This instrument was calibrated prior to use with indium, azobenzene, and undecane, purchased from Sigma-Aldrich (Madrid, Spain). Nitrogen was used to purge the system. Samples were prepared by pipetting 6-8 $\mathrm{mg}$ of the oils into aluminium pans, and weighing them using a Sartorius M2P electronic microbalance (Sartorius AG, Goettingen, Germany). The pans were then sealed and balanced calorimetrically, using an empty sealed capsule as the reference. The melting profile of the oils was determined by heating the samples at $90^{\circ} \mathrm{C}$ and holding for $5 \mathrm{~min}$ (in order to delete the thermal memory), then cooling to -80 ${ }^{\circ} \mathrm{C}$ at a rate of $10{ }^{\circ} \mathrm{C} / \mathrm{min}$ and holding for $20 \mathrm{~min}$. Finally, a ramp of $5^{\circ} \mathrm{C} / \mathrm{min}$ up to $90^{\circ} \mathrm{C}$ was applied to obtain data from the melting thermogram. The crystallization profile was obtained by completely melting the oils at $90{ }^{\circ} \mathrm{C}$ for $5 \mathrm{~min}$, and decreasing the temperature to $-80^{\circ} \mathrm{C}$ at a rate of $10{ }^{\circ} \mathrm{C} / \mathrm{min}$.

\section{RESULTS AND DISCUSSION}

\subsection{Oil Content}

The study of the oil content ( $\%$ dry weight) of the two varieties of $P$. persica in the two locations, Morneg $(\mathrm{Mg})$ and Gabes $(\mathrm{Gb})$, revealed slight differences between the samples. Depending on their growth location, an oil content ranging from $51.4 \pm 0.2 \%$ for nectarine to $53.7 \pm 0.3 \%$ for peach was found in the Mg cultivar; and $49.4 \pm 0.1 \%$ and $50.5 \pm 0.3 \%$, respectively, in the Gb cultivar. In both locations, the peach kernels exhibited the highest levels of oil content. As shown in Table 1, these results are within the values previously reported in the literature for the oil content of peach and nectarine dried kernels, ranging from $42.2 \%$ in Canadian fruits (Kamel and Kakuda, 1992) to $54.5 \%$ in Egyptian fruits (Rahma and Abd El-Aal, 1988). Furthermore, the oil contents were comparable with those of other oil crops of commercial interest, such as sunflower and rapeseed. The silica column fractionation of kernel oils from both P. Persica varieties showed that more than $98 \%$ of total lipids were 
TABLE 1. Oil contents (\%) and fatty acids compositions (mol\%) of peach and nectarine kernels harvested in different countries described previously in the literature

\begin{tabular}{|c|c|c|c|c|c|c|c|c|c|c|c|}
\hline & \multirow[b]{2}{*}{ Oil (\%) } & \multicolumn{9}{|c|}{ Fatty acids composition $\left(\mathrm{mol}^{\%} \%\right)$} & \multirow[b]{2}{*}{ Country } \\
\hline & & & 16:0 & 16:1 & 18:0 & 18:1 & 18:1A & 18:2 & $18: 3$ & 20:0 & \\
\hline \multirow[t]{12}{*}{ Peach } & 54.5 & $\mathrm{a}$ & 13.4 & 0.2 & 6.4 & 63.8 & & 15.4 & & & Egypt \\
\hline & 48 & $\mathrm{~b}$ & 6.3 & 0.4 & 1.7 & 69.0 & & 22.0 & 0.1 & 0.1 & Greece \\
\hline & 42.2 & $\mathrm{c}$ & 8.1 & 0.4 & & 58.5 & & 32.8 & & 0.3 & Canada \\
\hline & 43 & $\mathrm{~d}$ & 4.6 & 0.6 & 1.3 & 64.5 & 1.4 & 27.3 & 0.1 & 0.1 & Egypt \\
\hline & & $\mathrm{e}$ & 6.1 & & 1.8 & 32.5 & & 59.8 & & & Russia \\
\hline & 50.4 & f & 5.9 & 0.0 & 1.6 & 70.3 & 1.2 & 19.5 & 0.1 & 0.1 & Turkey \\
\hline & & g & 6.0 & 0.5 & 2.1 & 74.6 & & 15.7 & 0.1 & 0.2 & Spain \\
\hline & & $\mathrm{g}$ & 6.2 & 0.6 & 2.1 & 72.2 & & 18.1 & 0.1 & 0.2 & Spain \\
\hline & 44 & $\mathrm{~h}$ & 6.2 & 0.3 & 2.4 & 70.5 & & 20.5 & 0.0 & 0.2 & Brazil \\
\hline & & $\mathrm{i}$ & 8.4 & 0.3 & 1.2 & 41.1 & & 48.4 & 0.3 & 0.2 & Brazil \\
\hline & & $\mathrm{j}$ & 5.7 & 0.3 & 2.0 & 65.8 & & 25.9 & 0.1 & 0.0 & Canada \\
\hline & 39.5 & $\mathrm{k}$ & 5.9 & & & 57.5 & & 25.4 & & 6.2 & Turkey \\
\hline \multirow[t]{2}{*}{ Nectarine } & 43.8 & $\mathrm{c}$ & 6.1 & 0.5 & & 66.3 & & 26.8 & & 0.3 & Canada \\
\hline & & $\mathrm{e}$ & 6.1 & & 4.5 & 38.6 & & 50.6 & & & Russia \\
\hline
\end{tabular}

a, Rahma and Abd El-Aal (1988); b, Lazos (1991); c, Kamel and Kakuda (1992); d, Hassanein (1999); e, Deineka et al. (2002); f, Matthäus and Özcan (2009); g, Sánchez-Vicente et al. (2009); h, Mezzomo et al. (2010); i, Pelentir et al. (2011); j, Wu et al. (2011) and k, Özcan et al. (2015).

in the form of neutral lipids and only a very small amount corresponded to the polar fraction.

\subsection{Fatty acids composition}

The fatty acids profile, total saturated fatty acids (SFA), monounsaturated fatty acids (MUFA) and polyunsaturated fatty acids (PUFA) of nectarine and peach kernel oils can be found in Table 2. Six fatty acid species were identified in all the samples. Qualitatively, the fatty acids compositions in both varieties and provenances were similar. Both kernel oils are characterized by the predominance of MUFA, reaching its highest level $(76.6 \%)$ for those grown in $\mathrm{Mg}$. Oleic acid was the major FA in all the samples, accounting for $67.7 \%(\mathrm{~N} \mathrm{~Gb})$ to $75.0 \%$ $(\mathrm{N} \mathrm{Mg})$, followed by linoleic acid and saturated fatty acids (palmitic and stearic). Thus, the location of cultivars influenced the fatty acids profile of $P$. persica kernel: nectarine and peach kernel oils from $\mathrm{Mg}$ contained more oleic acid than kernel oils from $\mathrm{Gb}$. By contrast, higher levels of linoleic acid and palmitic acid were found for nectarine and peach from the $\mathrm{Gb}$ station.

In fact, these samples of kernel oils showed levels of oleic acid similar to high oleic sunflower oil (87.2\%). Thus, P. persica kernel oils can be considered as high oleic oils. These results are in agreement with those reported in the literature (Table 1) such as Spanish $P$. persica kernels that showed a high content of oleic acid $(74.6 \%)$, followed by linoleic acid (15.7\%), and palmitic acid (6.0\%) (Sánchez-Vicente et al., 2009).

\subsection{Triacylglycerol species composition}

The analysis of the TAG composition showed variability according to the species and locations of the studied cultivars (Table 3). Fourteen molecular species of TAG were detected, with the predominant ones being those containing oleic, linoleic and palmitic acids. The results showed that OOO (triolein) was the main TAG species, followed by OOL, POO, OLL and POL in all P. persica kernel oils. Regarding the influence of the provenance, Table 3 shows that the nectarine oils grown in $\mathrm{Mg}$ exhibited the highest value of $\mathrm{OOO}$ and $\mathrm{POO}$, according to the increasing oleic acid levels. When comparing both $P$. persica varieties, peaches $v s$ nectarines, it was found that in the $\mathrm{Mg}$ location the peach kernel oil showed the highest content of TAGs species OOL, POO, OLL and POL compared to nectarine, which showed only an increase in OOO. For the Gb location, smaller differences were detected due to the very similar fatty acid compositions of their oils (Table 2). As observed in Table 3, P. persica kernel oils presented some similarities with high oleic sunflower oil, being OOO $(69.2 \%)$ and POO $(9.2 \%)$ the main TAG species. The TAG compositions of the P. persica oils were also similar to some rosaceae kernel oils, such as apricot $(P$. armeniaca), plum $(P$. domestica) and peach (P. persica) (Hassanein, 1999), which showed average contents of OOO $(40.7 \%)$ and OOL $(24.8 \%)$ as the major TAGs components.

The contents of the TAG subclasses di-saturated (SUS), mono-saturated (SUU), and tri-unsaturated (UUU) were obtained from the compositions of the 
TAble 2. Oil contents and fatty acid compositions of Prunus persica kernel oils from different varieties, nectarine and peach, grown in two locations (Morneg, $\mathrm{Mg}$, and Gabes, $\mathrm{Gb}$ ) and high oleic sunflower oil (HOSO). Data are the mean of independent samples with SD lower than $3 \%$ of the mean value

\begin{tabular}{|c|c|c|c|c|c|}
\hline & \multicolumn{2}{|c|}{ Nectarine } & \multicolumn{2}{|c|}{ Peach } & \multirow[b]{2}{*}{ HOSO } \\
\hline & Mg & Gb & Mg & Gb & \\
\hline $\begin{array}{l}\text { Oil content } \\
(\% \text { DW) }\end{array}$ & 51.4 & 49.4 & 53.7 & 50.5 & \\
\hline \multicolumn{6}{|l|}{$\begin{array}{l}\text { Fatty acids } \\
(\% \mathrm{w} / \mathrm{w})\end{array}$} \\
\hline $16: 0$ & 5.7 & 6.3 & 5.6 & 6.1 & 4.0 \\
\hline $16: 1$ & 0.4 & 0.4 & 0.4 & 0.4 & 0.0 \\
\hline 18:0 & 2.0 & 2.0 & 1.9 & 1.9 & 3.8 \\
\hline $18: 1$ & 75.0 & 67.7 & 73.6 & 69.3 & 87.2 \\
\hline $18: 1 \mathrm{a}$ & 1.2 & 1.4 & 2.4 & 1.7 & 0.0 \\
\hline 18:2 & 15.7 & 22.1 & 16.0 & 20.5 & 3.4 \\
\hline $20: 0$ & 0.0 & 0.0 & 0.0 & 0.0 & 0.4 \\
\hline $22: 0$ & 0.0 & 0.0 & 0.0 & 0.0 & 1.2 \\
\hline$\Sigma \mathrm{SFA}$ & 7.7 & 8.3 & 7.5 & 8.0 & 9.4 \\
\hline$\Sigma$ MUFA & 76.6 & 69.5 & 76.5 & 71.4 & 87.2 \\
\hline$\Sigma$ PUFA & 15.7 & 22.1 & 16.0 & 20.5 & 3.4 \\
\hline
\end{tabular}

DW, Dry weight; 16:0, palmitic acid; 16:1, palmitoleic acid; 18:0, stearic acid; 18:1, oleic acid; 18:1a, asclepic acid; 18:2, linoleic acid; 20:0 arachidic acid; 22:0 behenic acid. SFA, Saturated, MUFA, Monounsaturated, and PUFA, Polyunsaturated fatty acids.

TAG species and the coefficient $\alpha$ (Martínez-Force et al., 2009) was used to calculate the asymmetry of saturated fatty acids between the $s n-1$ and $s n-3$ TAG positions (Table 3 ). The coefficient $\alpha$ varied between 0.10 and 0.12 (P Mg and $\mathrm{N} \mathrm{Mg}$, respectively) and between 10 and $12 \%$ saturated fatty acids were found in one external position and between 88 and $90 \%$ in the other position. This asymmetry is due to the enzymatic machinery responsible for the esterification of saturated fatty acids in the external positions, mainly glycerol-3-P acyltransferase and diacylglycerol acyltransferase. These results are similar to those reported for hazelnut and walnut oils, which exhibited low $\alpha$ coefficients $(0.17$ and 0.04 , respectively) and, therefore present a high asymmetry in their saturated fatty acids. However, the studied P. persica oils were quite different from soybean, high-stearic sunflower or rice which showed a higher $\alpha$ coefficient value $(0.29,0.33$, and 0.49 , respectively), corresponding to more symmetrical distributions of saturated fatty acids in their TAG species (Martínez-Force et al., 2004). The distribution of fatty acids in the three positions of TAG molecules has been studied in P. persica oils in the two locations (Table 4). These results confirmed that saturated fatty acid (palmitic and stearic acid) were mainly distributed in the external position $(s n-1,3)$ of the TAG backbone; whereas the $s n-2$ position mostly contained unsaturated fatty acids, of which more than $80 \%$ corresponding to oleic acid. These data, together with the low values of $\alpha$ coefficients can explain the strong asymmetrical distribution of the fatty acids, and hence, the absence of di-saturated species of TAGs (SUS) in these oils. Therefore, Prunus persica oils are composed exclusively of TAG species with two or more unsaturated fatty acids in their molecules (SUU and UUU), something that would be reflected in their thermal properties.

\subsection{Calorimetric analysis by DSC}

The DSC thermograms of $P$. persica kernel oils can be found in Figure 1: heating curves or melting profiles (Figure 1A) and cooling curves or crystallization profiles (Figure 1B). In addition, Table 5 provides thermal parameters obtained from the thermograms depicted in Figure 1. Heating curves from -80 to $80^{\circ} \mathrm{C}$ showed the melting profiles with an endothermic phase transition with a single and well-defined peak. The melting peaks in the DSC thermograms corresponding to P. Persica kernel oils exhibited an onset temperature with values between -46.9 to $-33.6{ }^{\circ} \mathrm{C}$ for the nectarine $\mathrm{Gb}$ and peach $\mathrm{Gb}$ varieties, respectively. High oleic sunflower oil started to melt at higher temperature $\left(-21.5^{\circ} \mathrm{C}\right)$. The melting temperature for the peak $\left(\mathrm{P}_{\mathrm{m}}\right)$ showed values from $-14.0{ }^{\circ} \mathrm{C}$ (nectarine $\mathrm{Gb}$ ) to $-9.4{ }^{\circ} \mathrm{C}$ (high oleic sunflower oil). For the temperature of end melting, it showed values ranging between -3.3 and $4.7^{\circ} \mathrm{C}$ for the $\mathrm{P} \mathrm{Gb}$ and $\mathrm{N} \mathrm{Mg}$ varieties, respectively. Again, high oleic sunflower exhibited a higher temperature for end melting $\left(5.2{ }^{\circ} \mathrm{C}\right)$. In general, it can be observed that for varieties with higher PUFA contents, lower melting temperatures were obtained. 
TABle 3. TAG species compositions (mol\%) of Prunus persica kernel oils from different varieties, nectarine and peach, grown in two locations (Morneg, $\mathrm{Mg}$, and Gabes, $\mathrm{Gb}$ ) and high oleic sunflower oil (HOSO). Data are the mean of independent samples with SD lower than $3 \%$ of the mean value

\begin{tabular}{|c|c|c|c|c|c|}
\hline & \multicolumn{2}{|c|}{ Nectarine } & \multicolumn{2}{|c|}{ Peach } & \multirow[b]{2}{*}{ HOSO } \\
\hline & Mg & Gb & Mg & Gb & \\
\hline POSt & 0.0 & 0.0 & 0.0 & 0.0 & 0.5 \\
\hline POO & 9.0 & 8.3 & 9.7 & 8.3 & 9.2 \\
\hline POL & 5.5 & 8.4 & 6.5 & 7.9 & 0.7 \\
\hline PLL & 1.2 & 2.1 & 1.4 & 2.0 & 0.0 \\
\hline StOO & 3.5 & 2.7 & 3.5 & 2.9 & 8.9 \\
\hline OOO & 50.5 & 38.4 & 47.3 & 39.6 & 69.2 \\
\hline StOL & 2.8 & 3.5 & 2.9 & 3.0 & 1.8 \\
\hline OOL & 18.2 & 22.3 & 19.8 & 23.2 & 3.8 \\
\hline StLL & 1.5 & 2.3 & 1.3 & 1.4 & 0.0 \\
\hline OLL & 6.3 & 10.1 & 6.7 & 9.7 & 0.9 \\
\hline LLL & 1.5 & 1.7 & 0.9 & 1.9 & 0.3 \\
\hline StOA & 0.0 & 0.0 & 0.0 & 0.0 & 0.4 \\
\hline OOA & 0.0 & 0.0 & 0.0 & 0.0 & 1.4 \\
\hline OLA & 0.0 & 0.0 & 0.0 & 0.0 & 0.5 \\
\hline OOB & 0.0 & 0.0 & 0.0 & 0.0 & 2.4 \\
\hline SUS & 0.0 & 0.0 & 0.0 & 0.0 & 0.9 \\
\hline SUU & 23.6 & 27.4 & 25.3 & 25.6 & 24.9 \\
\hline UUU & 76.4 & 72.6 & 74.7 & 74.7 & 74.2 \\
\hline$\alpha$ Sat & 0.12 & 0.11 & 0.10 & 0.11 & 0.11 \\
\hline
\end{tabular}

TAG were named with 3 letters. $P$, palmitic acid; O, oleic acid; St, stearic acid; L, linoleic acid; A, arachidic acid; and B, behenic acid. SSS, sum of trisaturated TAG; SUS, disaturated TAG; SUU, monosaturated TAG; and UUU, triunsaturated TAG. Peaks accounting for less than $0.3 \%$ of total triacylglycerols were not integrated.

TABLE 4. Fatty acids compositions in TAG $s n-1,3$ and $s n-2$ positions (mol\%) of Prunus persica kernel oils from different varieties, nectarine $(\mathrm{N})$ and peach $(\mathrm{P})$, grown in two locations (Morneg, $\mathrm{Mg}$, and Gabes, Gb). Data are the mean of independent samples with SD lower than $3 \%$ of the mean value

\begin{tabular}{lccccccc}
\hline & & \multicolumn{5}{c}{ Fatty acids composition } \\
\cline { 3 - 7 } & & $\mathbf{1 6 : 0}$ & $\mathbf{1 6 : 1}$ & $\mathbf{1 8 : 0}$ & $\mathbf{1 8 : 1}$ & $\mathbf{1 8 : 1 a}$ & $\mathbf{1 8 : 2}$ \\
\hline $\mathrm{N} \mathrm{Mg}$ & $s n-1,3$ & 8.1 & 0.6 & 2.4 & 69.5 & 1.5 & 18.0 \\
& $s n-2$ & 1.0 & 0.0 & 1.2 & 86.1 & 0.6 & 11.1 \\
$\mathrm{~N} \mathrm{~Gb}$ & $s n-1,3$ & 9.1 & 0.6 & 2.7 & 57.8 & 1.6 & 28.0 \\
& $s n-2$ & 0.6 & 0.0 & 0.6 & 87.5 & 0.9 & 10.3 \\
$\mathrm{P} \mathrm{Mg}$ & $s n-1,3$ & 8.0 & 0.6 & 2.4 & 69.8 & 3.3 & 15.7 \\
& $s n-2$ & 0.8 & 0.0 & 0.8 & 81.2 & 0.7 & 16.6 \\
$\mathrm{P} \mathrm{Gb}$ & $s n-1,3$ & 8.9 & 0.6 & 2.7 & 63.1 & 2.1 & 22.5 \\
& $s n-2$ & 10.5 & 0.0 & 4.0 & 77.2 & 1.4 & 7.0 \\
\hline
\end{tabular}

16:0, palmitic acid; 16:1, palmitic oleic acid; 18:0, stearic acid; 18:1 $\Delta 9$, oleic acid; 18:1 $\Delta 11$, asclepic cacid; 18:2, linoleic acid.

The range of transition phase $(\mathrm{R})$ for the melting curves (temperature difference between $\mathrm{T}_{\text {onset } \mathrm{m}}$ and $\mathrm{T}_{\text {end } \mathrm{m}}$ ) was higher for kernel oils compared to high oleic sunflower oil. Kernel oils contained higher amounts of the tri-unsaturared TAG species OOL and LLL, and of the mono-saturated TAG species
POL and PLL. Since these TAGs species exhibit lower melting points than other mono-saturated (StOO, OOA and OOB) and di-saturated (POSt and StOA) TAGs species, only present in high oleic sunflower oil, the melting range of kernel oil was lower. Regarding the melting enthalpy, kernel oils showed 
(a)

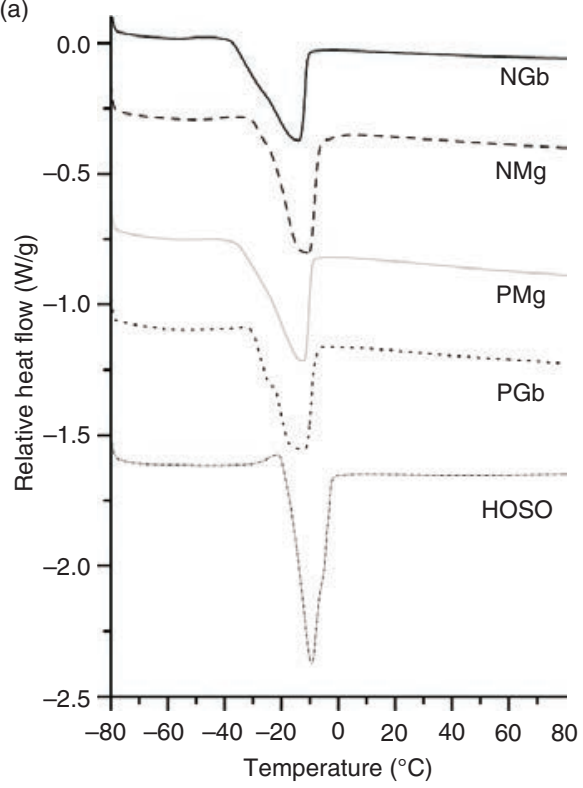

(b)

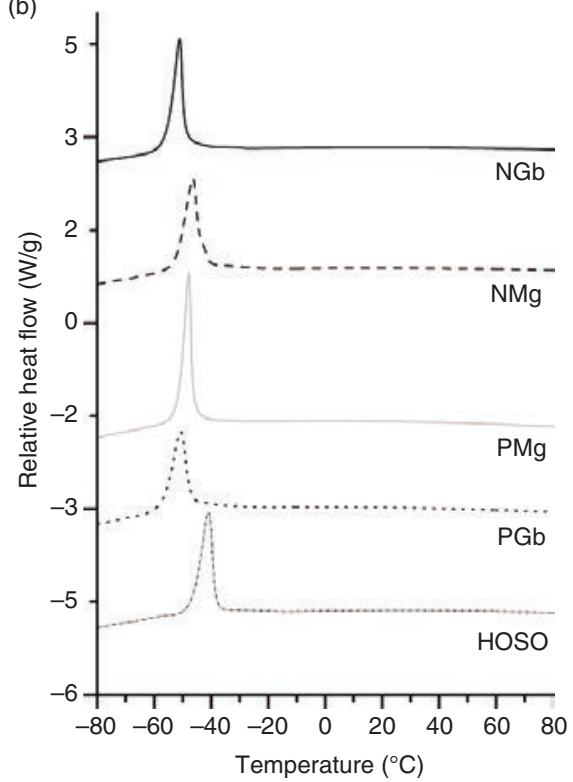

FIgURE 1. DSC thermograms of Prunus persica kernel oils from different varieties (Nectarine, N, and Peach,P) grown in two locations (Morneg, Mg, and Gabes, Gb) and high oleic sunflower oil (HOSO): (a) melting curves, and (b) crystallization curves

TABLE 5. DSC parameters obtained from the thermograms for Prunus persica kernel oils from different varieties, nectarine and peach, grown in two locations (Morneg, Mg, and Gabes, Gb) and high oleic sunflower oil (HOSO). Data are the mean of independent samples with SD lower than $3 \%$ of the mean value

\begin{tabular}{|c|c|c|c|c|c|}
\hline & \multicolumn{2}{|c|}{ Nectarine } & \multicolumn{2}{|c|}{ Peach } & \multirow[b]{2}{*}{ HOSO } \\
\hline & Mg & Gb & Mg & Gb & \\
\hline \multicolumn{6}{|l|}{ Melting Curves: } \\
\hline$\triangle \mathrm{H}_{\mathrm{m}}(\mathrm{J} / \mathrm{g})$ & 77.0 & 65.6 & 69.1 & 70.4 & 85.3 \\
\hline $\mathrm{P}_{\mathrm{m}}\left({ }^{\circ} \mathrm{C}\right)$ & -11.5 & -14.0 & -12.2 & -12.1 & -9.4 \\
\hline T onset $\mathrm{m}\left({ }^{\circ} \mathrm{C}\right)$ & -35.9 & -46.9 & -43.7 & -33.6 & -21.5 \\
\hline $\mathrm{T}^{\mathrm{T}}$ end $\mathrm{m}\left({ }^{\circ} \mathrm{C}\right)$ & 4.7 & -2.9 & 0.3 & -3.3 & 5.2 \\
\hline $\mathrm{R}\left({ }^{\circ} \mathrm{C}\right)$ & 31.3 & 44.0 & 43.4 & 30.3 & 16.3 \\
\hline \multicolumn{6}{|l|}{$\begin{array}{l}\text { Crystallization } \\
\text { Curves: }\end{array}$} \\
\hline$\triangle \mathrm{H}_{\mathrm{c}}(\mathrm{J} / \mathrm{g})$ & 63.7 & 59.2 & 62.6 & 57.0 & 60.5 \\
\hline $\mathrm{P}_{\mathrm{c}}\left({ }^{\circ} \mathrm{C}\right)$ & -46.2 & -51.1 & -47.9 & -50.7 & -41.0 \\
\hline T onset $\left({ }^{\circ} \mathrm{C}\right)$ & -26.2 & -29.5 & -30.2 & -29.5 & -16.8 \\
\hline $\mathrm{T}$ end ${ }_{\mathrm{c}}\left({ }^{\circ} \mathrm{C}\right)$ & -60.0 & -64.0 & -60.2 & -64.2 & -58.5 \\
\hline $\mathrm{R}\left({ }^{\circ} \mathrm{C}\right)$ & 33.8 & 34.5 & 30.0 & 34.7 & 41.7 \\
\hline
\end{tabular}

$\triangle \mathrm{H}_{\mathrm{m}}$ : melting enthalpy, $\mathrm{P}_{\mathrm{m}}$ : temperature of the major peak of melting, $\mathrm{T}$ onset $\mathrm{m}_{\mathrm{m}}$ and $\mathrm{T}$ end $\mathrm{m}$ : initial and end temperature of the melting phase, $\triangle \mathrm{H}_{\mathrm{c}}$ : crystallization enthalpy, $\mathrm{P}_{\mathrm{c}}$ : temperature of the major peak of crystallization, $\mathrm{T}$ onset $_{\mathrm{c}}$ and $\mathrm{T}$ end $\mathrm{c}_{\mathrm{c}}$ : initial and end temperature of the crystallization phase, $\mathrm{R}$ : range of the transition phase (temperature difference between $\mathrm{T}$ onset and $\mathrm{T}$ end).

lower values compared to high oleic sunflower oil. As reported in the literature, lower melting enthalpy values indicate weaker crystalline structures. Thus, less energy would have to be absorbed to destroy the crystal network (Willie and Luton, 1966).
Cooling curves from 80 to $-80^{\circ} \mathrm{C}$, showed the crystallization profiles corresponding to an exothermic event with a single and well-defined peak for both kernel and sunflower oils. For kernel oils, the crystallization peak in the DSC thermograms showed 


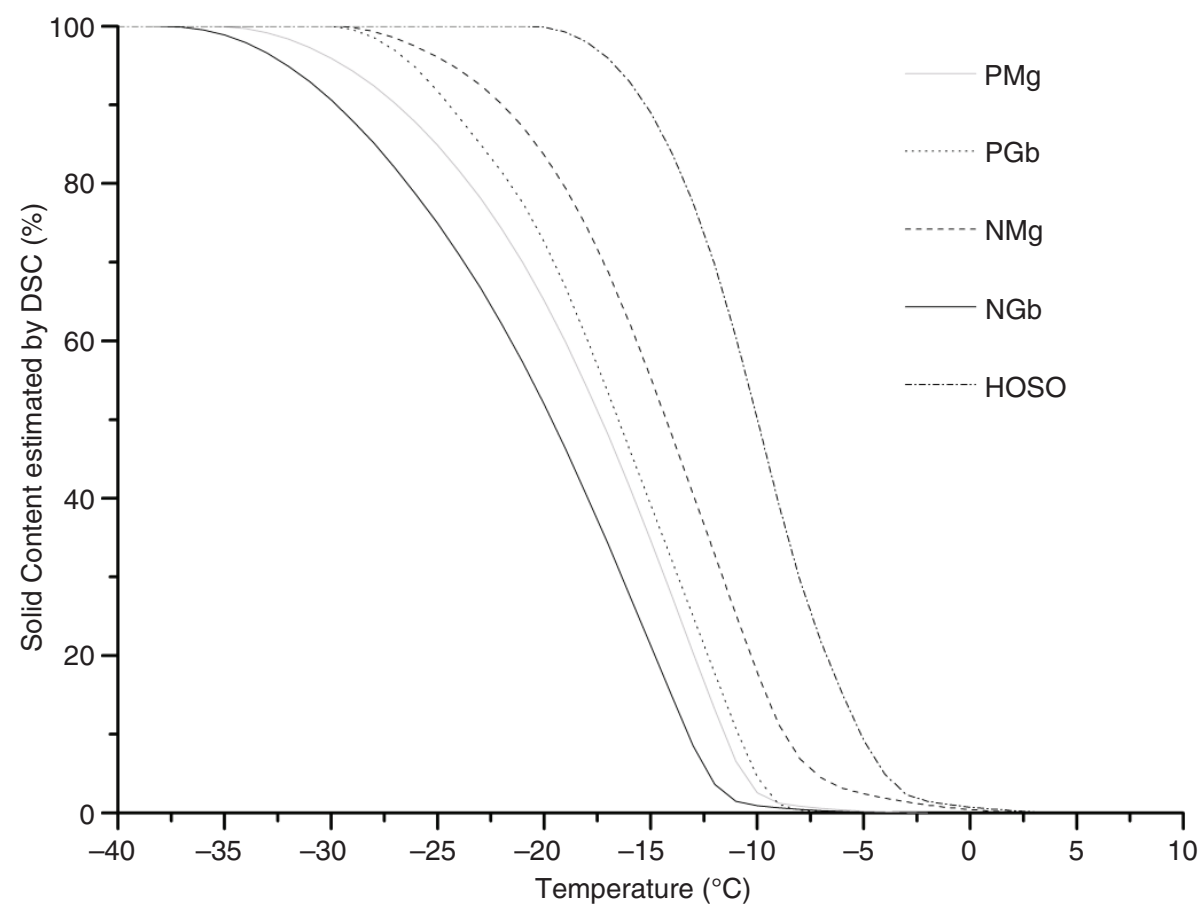

FIgURe 2. Solid contents estimated by DSC of Prunus persica kernel oils from different varieties (Nectarine, N, and Peach, P) grown in two locations (Morneg, $\mathrm{Mg}$, and Gabes, $\mathrm{Gb}$ ) and high oleic sunflower oil (HOSO)

an initial temperature of crystallization $\left(\mathrm{T}_{\text {onset }} \mathrm{c}\right)$ with values from -30.2 to $-26.2^{\circ} \mathrm{C}$, whereas the peak for temperature crystallization $\left(\mathrm{P}_{\mathrm{c}}\right)$ reached values between -51.1 and $-46.2^{\circ} \mathrm{C}$. High oleic sunflower oil exhibited higher values for $\mathrm{T}_{\text {onset } \mathrm{c}}\left(-16.8^{\circ} \mathrm{C}\right)$ and $\mathrm{P}_{\mathrm{c}}$ $\left(-41{ }^{\circ} \mathrm{C}\right)$. These differences for peak maximum and crystallization temperature ranges may be attributed to the higher levels of long chain saturated fatty acids (arachidic and behenic acids) and the SUS type TAGs present in high oleic sunflower oil. These di-saturated TAGs species crystallize at temperatures slightly higher than SUU and UUU TAGs, so for high oleic sunflower oil the crystallization took place at a higher interval of temperature than in kernel oils. The estimation of solid content (Figure 2) was calculated by integration of the melting thermograms using the analysis software provided by the DSC manufacturer. High oleic sunflower oil displayed a higher solid content and a sharper curve compared to kernel oils. So, at $-20^{\circ} \mathrm{C}$, kernel oils containing less $\mathrm{OOO}$, displayed lower contents of solids (about $55 \%$ and $70 \%$ of solid content for $\mathrm{N} \mathrm{Gb}$ and $\mathrm{P} \mathrm{Mg}$, respectively), whereas high oleic sunflower oil was $100 \%$ solid at that temperature. At $-10{ }^{\circ} \mathrm{C}$, all kernel oils were melted except for $\mathrm{N} \mathrm{Mg}$, whose solid content was close to $20 \%$. The kernel oil with the highest $\mathrm{OOO}$ content was $\mathrm{N} \mathrm{Mg}$, and was completely melted around $0{ }^{\circ} \mathrm{C}$ (similar to high oleic sunflower oil).

In summary, the melting and crystallization behavior of both $P$. persica varieties from different locations showed similar shapes with a unique peak and DSC parameters with different values depending on the variety and provenance (Table 5). The small variations observed in the DSC profiles are in good agreement with the changes in TAG species found between varieties and locations (Table 3). Although the major peak observed for all samples was mainly due to the triolein content, the higher levels of linoleic acid present in the $P$. persica kernel oils also contributed to modifying their thermal behaviour compared with high oleic sunflower oil.

\section{ACKNOWLEDGEMENTS}

This research was funded by the Tunisian Ministry of Higher Education and Scientific Research. The authors wish to thank $\mathrm{M}^{\mathrm{a}}$ Soledad Parra Camacho for her technical assistance with GC determinations.

\section{REFERENCES}

Bates RP, Pierce R, Morris JR, Crandall PG. 2001. Tree fruit: Apple, pear, peach, plum, apricot and plums; in Bates RP, Pierce R, Morris JR, Crandall PG (Eds.) Principles and practices of small-and medium-scale fruit juice processing. FAO Agricultural Services Bulletin 146, FAO, Rome, 151-169.

Bootello MA, Garcés R, Martínez-Force E, Salas JJ. 2016. Effect of the distribution of saturated fatty acids in the melting and crystallization profiles of high-oleic high-stearic oils. Grasas Aceites 67, e149. http://dx.doi.org/10.3989/gya.0441161

Cantín CM, Gogorcena Y, Moreno MA. 2009. Evaluation of the antioxidant capacity, phenolic compounds, and vitamin C content of different peach and nectarine [Prunus persica (L.) Batsch] breeding progenies. J. Agric. Food Chem. 57, 4586-4592. http://dx.doi.org/10.1021/jf900385a 
Deineka VI, Gabruk NG, Deineka LA, Manokhina LA. 2002. Triglyceride composition of oil from stones of nine Rosaceae plants. Chem. Nat. Comp. 38, 410-412. http:// dx.doi.org/10.1023/A:1022147207053

Di Vaio C, Graziani G, Marra L, Cascone A, Ritieni A. 2008. Antioxidant capacities, carotenoids and polyphenols evaluation of fresh and refrigerated peach and nectarine cultivars from Italy. Eur. Food Res. Technol. 227, 1225-1231. http://dx.doi.org/10.1007/s00217-008-0840-z

FAOSTAT (2013) http://faostat3.fao.org/

Garcés R, Mancha M. 1993. One-step lipid extraction and fatty acid methyl esters preparation from fresh plant tissues. Anal. Biochem. 211, 139-143. http://dx.doi.org/10.1006/ abio.1993.1244

Gilani AH, Aziz N, Ali SM, Saeed M. 2000. Pharmacological basis for the use of peach leaves in constipation. $J$. Ethnopharmacol. 73, 87-93. http://dx.doi.org/10.1016/ S0378-8741(00)00288-9

Hassanein MMM. 1999. Studies on non-traditional oils: I. Detailed studies on different lipid profiles of some Rosaceae kernel oils. Grasas Aceites 50, 379-384. http:// dx.doi.org/10.3989/gya.1999.v50.i5.682

Kamel BS, Kakuda Y. 1992. Characterization of the seed oil and meal from apricot, cherry, nectarine, peach and plum. J. Am. Oil Chem. Soc. 69, 492-494. http://dx.doi.org/10.1007/BF02540957

Lazos ES. 1991. Composition and oil characteristics of apricot, peach and cherry kernel. Grasas Aceites 42, 127-131. http://dx.doi.org/10.3989/gya.1991.v42.i2.1260

Martínez-Force E, Ruiz-López N, Garcés R. 2004. The determination of the asymmetrical stereochemical distribution of fatty acids in triacylglycerols. Anal. Biochem. 334, 175-182. http://dx.doi.org/10.1016/j.ab.2004.07.019

Martínez-Force E, Ruiz-López N, Garcés R. 2009. Influence of specific fatty acids on the asymmetric distribution of saturated fatty acids in sunflower (Helianthus annuus L.) triacylglycerols. J. Agric. Food Chem. 57, 1595-1599. http:// dx.doi.org/10.1021/jf803227n

Matthäus B, Ôzcan MM. 2009. Fatty acids and tocopherols contents of some Prunus Spp. kernel oils. J. Food Lipids 16, 187-199. http://dx.doi.org/10.1111/j.1745-4522.2009.01140.x

Mezzomo N, Mileo BR, Friedrich MT, Martínez J, Ferreira SRS. 2010. Supercritical fluid extraction of peach (Prunus persica) almond oil: Process yield and extract composition. Bioresour. Technol. 101, 5622-5632. http://dx.doi. org/10.1016/j.biortech.2010.02.020

Mezzomo N, Martínez J, Ferreira SRS. 2009. Supercritical fluid extraction of peach (Prunus persica) almond oil: Kinetics, mathematical modeling and scale-up. J. Supercrit. Fluids 51, 10-16. http://dx.doi.org/10.1016/j.supflu.2009.07.008

Miraliakbari H, Shahidi F. 2008. Lipid class compositions, tocopherols and sterols of tree nut oils extracted with different solvents. J. Food Lipids 15, 81-96. http://dx.doi. org/10.1111/j.1745-4522.2007.00104.x

Nash AM, Frankel EN. 1986. Limited extraction of soybean with hexane. J. Am. Oil Chem. Soc. 63, 244-246. http:// dx.doi.org/10.1007/BF02546147
Ôzcan MM, Ünver A, Arslan D. 2015. A research on evaluation of some fruit kernels and/or seeds as a raw material of vegetable oil industry. Qual. Assur. Saf. Crop. 7, 187-191. http://dx.doi.org/10.3920/QAS2013.0319

Pelentir N, Block JM, Monteiro Fritz AR, Reginatto V, Amante ER. 2011. Production and chemical characterization of peach (Prunus persica) kernel flour. J. Food Process Eng. 34, 1253-1265. http://dx.doi. org/10.1111/j.1745-4530.2009.00519.x

Rahma EH, Abd El-Aal MH. 1988. Chemical characterization of peach kernel oil and protein: Functional properties, in vitro digestibility and amino acids profile of the flour. Food Chem. 28, 31-43. http://dx.doi. org/10.1016/0308-8146(88)90004-0

Ram V, Bhardwaj LN. 2004. Stone fruit diseases and their management, in Naqvi SAMH (Ed.) Diseases of fruits and vegetables Vol. II. Kluwer Academic Publishers, Netherlands, 485-510. http://dx.doi.org/10.1007/1-4020-2607-2_13

Ruiz-López N, Martínez-Force E, Garcés R. 2003. Sequential one-step extraction and analysis of triacylglycerols and fatty acids in plant tissues. Anal. Biochem. 317, 247-254. http://dx.doi.org/10.1016/S0003-2697(03)00139-8

Sabate J, Hook DG. 1996. Almonds, walnuts, and serum lipids, in Spiller GA (Ed.) Handbook of lipids in human nutrition. CRC Press, Boca Raton, FL, USA, 137-144.

Sánchez-Vicente Y, Cabañas A, Renuncio JAR, Pando C. 2009. Supercritical fluid extraction of peach (Prunus persica) seed oil using carbon dioxide and ethanol. $J$. Supercrit. Fluids 49, 167-173. http://dx.doi.org/10.1016/j. supflu.2009.01.001

Socias i Company R, Kodad O, Alonso JM, Font-Forcada C. 2010. Fruit quality in almond: chemical aspects for breeding strategies, in Zakynthinos G (Ed.). XIV GREMPA Meeting on Pistachios and Almonds. Zaragoza. CIHEAM/ FAO/AUA/TEI Kalamatas/NAGREF, Athens, Greece, 235-243. http://hdl.handle.net/10532/1765

Sorci-Thomas M, Prack MM, Dashti N, Johnson F, Rudel LL, Williams DL. 1989. Differential effects of dietary fat on the tissue specific expression of the apolipoprotein A-I gene: relationship to plasma concentration of high density lipoproteins. J. Lipid Res. 30, 1397-1403.

Vander Wal RJ. 1960. Calculation of the distribution of the saturated and unsaturated acyl groups in fats, from pancreatic lipase hydrolysis data. J. Am. Oil Chem. Soc. 37, 18-20. http://dx.doi.org/10.1007/BF02630816

Visioli F, Poli A, Gall C. 2002. Antioxidant and other biological activities of phenols from olives and olive oil. Med. Res. Rev. 22, 65-75. http://dx.doi.org/10.1002/med.1028

Willie RL, Lutton ES. 1966. Polymorphism of cocoa butter. $J$. Am. Oil Chem. Soc. 43, 491-496. http://dx.doi.org/10.1007/ BF02641273

Wu H, Shi J, Xue S, Kakuda Y, Wang D, Jiang Y, Ye X, Li Y, Subramanian J. 2011. Essential oil extracted from peach (Prunus persica) kernel and its physicochemical and antioxidant properties. Food Sci. Technol. 44, 2032-2039. http:// dx.doi.org/10.1016/j.lwt.2011.05.012 